\section{CJLT}

Canadian Journal of Learning and Technology

La Revue canadienne de l'apprentissage et de la technologie

Volume $46(3)$

Fall/Automne 2020

\title{
Boundary Crossing between Formal and Informal Learning Opportunities: A Pathway for Advancing e-Learning Sustainability
}

\section{Le dépassement des frontières entre les possibilités d'apprentissage formel et informel : Une voie pour faire progresser la durabilité du e-learning}

\author{
Kathlyn Bradshaw, Algonquin College \\ Jennifer Lock, University of Calgary \\ Gale Parchoma, University of Saskatchewan
}

\begin{abstract}
In this article, third generation cultural historical activity theory (CHAT) (Engeström, 2011) will be the means for analyzing tensions and contradictions between formal and informal learning within a MOOC design. This article builds on previous work (Bradshaw et al., 2017) wherein CHAT was used to establish formal and informal learning as activity systems. Formal and informal learning are considered in relation to designing learning for a MOOC environment. Findings from an in situ study specifically examining CHAT elements in the process of design are considered in a movement towards making visible what those tasked with designing courses normally do not see in relation to informal learning. Implications for practice are presented in a CHAT-informed MOOC design model intended to augment typical approaches to instructional design. The outcome is an argument for CHAT-informed MOOC design model that can intentionally address both formal and informal opportunities for learning.
\end{abstract}

\section{Résumé}

Dans cet article, la théorie de l'activité historique culturelle de troisième génération (Engeström, 2011) sera le moyen d'analyser les tensions et les contradictions entre l'apprentissage formel et informel au sein d'une conception de MOOC. Cet article s'appuie sur des travaux antérieurs (Bradshaw et al., 2017) dans lesquels la théorie de l'activité historique culturelle a été utilisée pour établir l'apprentissage formel et informel en tant que systèmes d'activités. L'apprentissage formel et informel est considéré en relation avec la conception de l'apprentissage pour un environnement MOOC. Les résultats d'une étude in situ examinant spécifiquement les éléments de la théorie de l'activité historique culturelle dans le processus de conception sont considérés dans un mouvement visant à rendre visible ce que les personnes 
chargées de concevoir des cours ne voient normalement pas en ce qui concerne l'apprentissage informel. Les implications pour la pratique sont présentées dans un modèle de conception de MOOC informé par la théorie de l'activité historique culturelle destiné à augmenter les approches typiques de la conception pédagogique. Le résultat est un argument en faveur d'un modèle de conception de MOOC informé par la théorie de l'activité historique culturelle qui peut aborder intentionnellement les opportunités d'apprentissage formelles et informelles.

\section{Introduction}

This article builds on previous work (Bradshaw et al., 2017) that used cultural historical activity theory (CHAT) to establish formal and informal learning as activity systems. The current article differs from the earlier one because the focus here is on sustainable e-learning. Teaching with and through educational technologies includes pedagogical approaches that can advance sustainability via responding to social calls for broader access to higher education and for cost reductions. In the process of such approaches, learning contexts are altered. Learning contexts have sometimes been conceptualized as a dualism embedded in "the contrast between informal learning and the explicitly [formal] didactic instructional practices that have emerged in Western schooling” (Bransford et al., 2006, p. 23). Malcolm, Hodkinson, and Colley (2003) identify informal and formal learning as "essentially different," (p. 314) yet offer opportunities for "greater combinations" (p. 314) that meet diverse learner needs. Hall (2009) contended that formal and informal learning should be connected to optimize learning, and learning is most effective when learners engage in both formal and informal learning activities.

In this article, third generation CHAT (Engeström, 2011) will be the means for analyzing tensions and contradictions between formal and informal learning within a MOOC design. The article's purpose is threefold. First, we examine formal and informal learning in relation to designing learning for a MOOC environment. Second, we report findings from an in situ study specifically examining CHAT elements in the process of design, in a movement towards making visible what those tasked with designing courses normally do not see in relation to informal learning. Third, implications for practice are presented in a CHAT-Informed MOOC design model that can augment typical approaches to instructional design. We argue that a CHAT-Informed MOOC design model can intentionally address both formal and informal opportunities for learning. The article includes limitations and directions for future research and concludes with potential applications of findings to broader sustainable e-learning contexts.

\section{Formal and Informal eLearning}

A phenomenon at the centre of debates about designing MOOCs is the tension between formal and informal e-learning (Anders, 2015). Wright et al. (2013) identified three learning contexts: informal learning (typically found in non-institutional settings), non-formal learning (typically found in workplace settings), and formal learning (typically found in regulated institutions). 
Our discussion of MOOC design focuses on designing learning opportunities for formal and informal e-learning. Previous work on distinguishing informal from formal learning has emphasized differences between contexts, activities, and assessments. Learning online via Web 2.0 social media has been identified as having "informal, incidental, learner-initiated activities...delineated by absence of formal assessment" (Wright et al., 2013, p. 54). Informal learning has been contextualized as "outside any educational institutions or organized courses" (Livingstone, 2007, p. 2), and inclusive of "free choice, include a diverse and non-standardized range of topics," "flexible structures," and "socially rich interactions." Definitions of informal learning have excluded "institutional, curricular, and externally imposed authority" (Wright et al., 2013, p. 54) and externally imposed assessments" (Crowley et al., 2014, p. 466). Institutional driven e-learning (typically hosted within a learning management system or LMS) tends towards formality "where learning is aligned to planned outcomes from an accredited curriculum and organized by a teacher who has a hierarchical relationship with students" (Wright et al., 2013, p. 54). Formal learning has been described as: "(i) organized deliberately to fulfill the specific purpose of transmission, (ii) extracted from the manifold of daily life, placed in a special setting and carried out according to specific routines, and (iii) made the responsibility of the larger social group" (Scribner \& Cole, 1973, p. 555). Further, formal learning has been labelled as traditional or formal education where "learning experiences and outcomes are designed and assessed" (Wright et al., 2013, p. 54) and typically occur under the purview of regulated educational institutions. However, these categorical distinctions have also been problematized.

Conole (2014) suggested that learning "occurs along a spectrum from formal to informal; from loosely based resource-based learning to a structured time-defined course, which is accredited" (p. 72). Downes (2018) suggested "the formal learner is attempting to learn something, the informal learner is attempting to do something" (para. 33, italics his). Bunderup Dohn (2009) proposed examining the formal-to-informal learning continuum from a practice lens that problematizes formal notions of learning as acquisition (of knowledge and credentials) and informal notions of learning as participation in learning opportunities for "communication, knowledge construction, and knowledge sharing" (p. 349). She argued that it is possible to adopt pedagogical strategies that transcend categorical notions of acquisition and participation. Hall (2009) has posited that formal and informal learning should be connected to optimize learning and that learning is most effective when learners engage in both formal and informal learning activities. Sustainability in e-learning involves both recognizing and creating learning opportunities across formal and informal contexts. MOOCs are instances of attempts to do so.

\section{MOOCs}

To date, a great deal of time, energy, and money has been dedicated to the production and delivery of MOOCs. For instance, the University of California's UCOnline garnered a start-up loan of seven million USD (Vernon, 2013), while Coursera secured a \$43 million investment on top of \$22 million in venture capital raised (Lewin, 2013). The number of MOOCs available increases constantly. At the time of writing, Coursera (2017) had advertised 1,999 courses with 145 partner universities and 
other organizations from 28 countries. MOOCs have the potential for massive scales of enrollment (Downes, 2008), and class sizes can reach tens of thousands. The increasing numbers of both providers of, and participants in, MOOCs, combined with significant monetary investments, indicates MOOCs may not be simply a novel, short-lived trend in online course delivery, but a form of e-learning continuing to attract many supporters and participants.

The efficacy of MOOCs has been questioned, with those like Jordan (2014) pointing to "completion rates of less than $10 \%$ of those who enroll, with a median average of $65 \%$ " (p. 150), demonstrated not only dramatically high participant drop-out rates, but also low active participant rates. Participants in a MOOC face numerous challenges including the demands of "self-regulation" (Milligan et al., 2013, p. 157) and the need to "self-organize" (McAuley et al., 2010, p. 4), and the potential to feel "overwhelmed by technical issues" (Haber, 2014, p. 200).Designing for online learning opportunities has been affected by the "increased emergence of Web 2.0 applications" (Selwyn \& Simons, 2009, p. 2), and complexities that may arise from learning and teaching online, such as with a MOOC.

\section{MOOC Typologies}

MOOCs are often broadly positioned as either cMOOCs (based on connectivistic pedagogies) or xMOOCs (based on cognitivistic/behaviouristic pedagogies) (Anders, 2015). xMOOCs can be seen to adopt behaviouristic pedagogies implemented to tightly structure learning tasks directed toward predetermined generalized learning objectives, which predict "measurable effects on performance on tests or other direct measures of student outcomes" (Confrey, 2006, p. 136). Designers adhering to behaviourist theory thus would perceive learning tasks as those which elicit behaviour in response to stimuli (Schuh \& Barab, 2007). In contrast, cMOOCs are grounded in a connectivist conceptualization of learning that focuses on "learning that occurs outside of people" (Siemens, 2005, para. 12). Instructional designers guided by the connectivist theory are more likely to design tasks focused on "connecting specialized information sets" (Siemens, 2005, para. 16), within "a more individualised or personalised perspective on learning” (Ryberg et al., 2011, p. 51). Figure 1 summarizes these differences. 


\section{Figure 1}

Commonly Identified MOOC Types

\begin{tabular}{|l|l|l|}
\hline MOOC Types & \multicolumn{1}{|c|}{ Focus } & Level of Formality \\
\hline cMOOCs & $\begin{array}{l}\text { Students to choose what to learn and how: } \\
\text { create connections } \\
\text { make connections between concepts } \\
\text { build networks to keep current in a } \\
\text { field (Downes, 2012) }\end{array}$ & $\begin{array}{l}\text { Primarily informal } \\
\text { learning opportunities }\end{array}$ \\
\hline xMOOCs & $\begin{array}{l}\text { Mass access to the lectures, readings, } \\
\text { discussions, assignments, and assessments a }\end{array}$ & opportunities \\
\hline student would find in a traditional college & \\
\hline class (Haber, 2014) &
\end{tabular}

O'Toole (2013) argued that XMOOCs and cMOOCs are not only distinct but are also "extremes"; however, "basic pedagogical approaches are very similar" (p. 1). Course materials are held in "a hub or central repository," learners participate "through online forums, study groups, and (in Coursera and Udacity) organized meetings," and automated software is often used to assess learner performances on quizzes or other assignments (Johnson et al., 2013, p. 12). In his meta-analysis of MOOC designs, Anders' (2015) contended that primarily content-based xMOOCs and primarily networked-based cMOOC designs have been portrayed as "discrete types" (p. 46). Envisioning MOOCs as discrete types for categorization has been regarded as insufficient. Anders' argued that hybrid MOOC designs "balance the strengths and weaknesses of both XMOOC and cMOOC models" and can "support learning communities that offer highly social and dialogical learning experiences" (p. 46). Where Anders' conceptualization of hybrid MOOCs provides valuable insights for analyzing pre-existing MOOC designs, it is less applicable to supporting designers in the design process as they need to grapple with the complexities of meeting diverse learners' needs, intentions, and goals, and meeting the institutional needs for rigour and potentially for credentialing. In this complex design context where formal and informal learning opportunities are combined, designers can benefit from purposeful consideration of how to address sometimes aligned and other times competing agendas.

\section{Activity Theory}

Tensions between formal and informal e-learning opportunities can be envisioned as catalysts for boundary crossing. Engeström's (2009a) third generation activity theory identified boundary crossing as interactions between at least two activity systems that result from internal contradictions within a single 
activity system, which impede reaching a goal or solving a problem. Engeström described activity systems as a way of theorizing "complex interrelations between the individual subject and his or her community" (p. 55). Within an activity system, CHAT elements include mediating: (1) rules, (2) divisions of labour, (3) artefacts and/or instruments that influence how a, (4) subject engages with his or her, (5) community to accomplish a goal, and (6) an object.

Figure 2 depicts boundary crossing as occurring when members of Activity System A (formal learning) and B (informal learning) engage in sense-making: their shared object (Object 3) or goal (Engeström, 2009a). Engaging in shared sense-making can result in new, potentially jointly constructed approaches to solving a problem. In a MOOC design context, sense-making can be seen as collaborative knowledge construction that requires boundary crossing between formal and informal activity systems. Designed opportunities for learners to cross boundaries between formal and informal learning tasks and activities can result in the tensions that can form a new activity system.

\section{Figure 2}

\section{A Third Generation Activity System, Adapted from Bradshaw et al. (2017)}

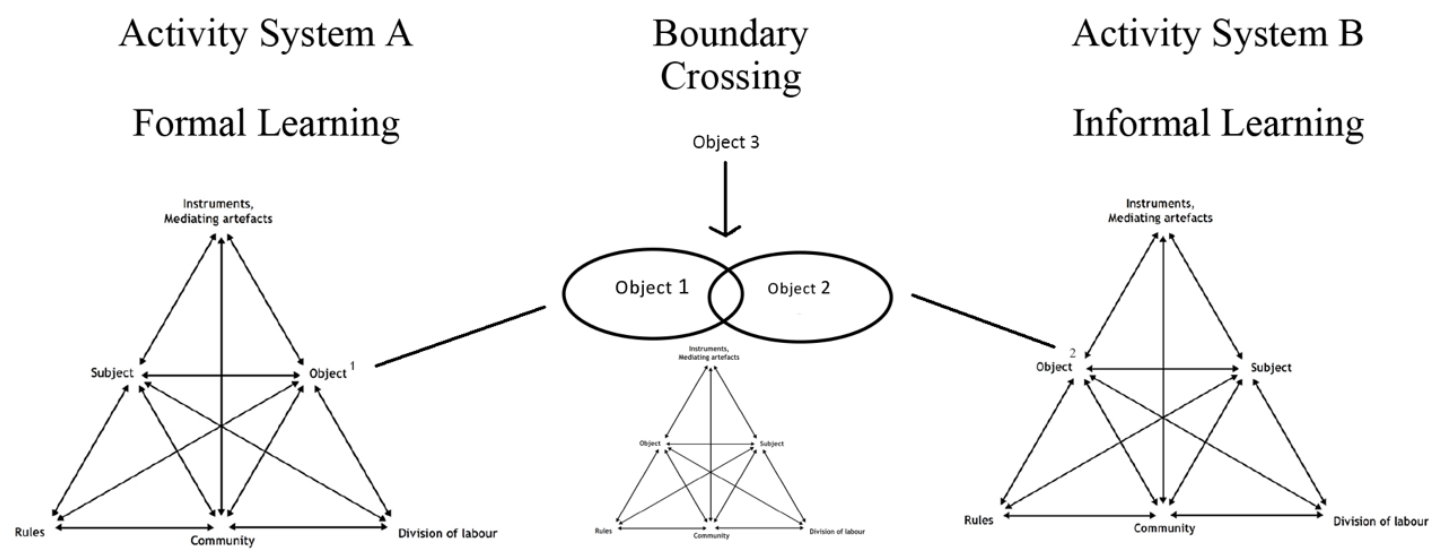

Examples of tensions, or as Engeström has more strongly asserted, examples of contradictions (Engeström, 2001), which can lead to boundary crossing between activity systems are associated with CHAT elements: (1) a "primary contradiction involves tensions arising anywhere within any of the CHAT elements"; (2) a "secondary contradiction involves tensions arising between CHAT elements"; (3) a "tertiary contradiction involves tensions arising between the new and the old activity system"; and (4) a "quaternary contradiction involving tensions arising between activity systems that may result in boundary crossings from one activity system to another" (Rückriem, 2009, p. 151). An example of a primary contradiction would be a tension caused by inconsistencies within a learning community's agreed upon set of rules. A secondary contradiction could arise when a mediating artefact, such as a LMS, is not helpful as a communication tool among a community of learners. Exclusive use of an LMS 
for informal learning opportunities with learners who are more familiar with Web 2.0 applications could cause a tertiary contradiction. Should this tertiary contradiction become unmanageable, tensions could escalate to a point where learners abandon the LMS altogether and work exclusively with Web 2.0 applications. In this latter example, their choice could be a coping mechanism for dealing with a quaternary contradiction.

Robertson (2008) employed third generation CHAT to "contribute to change management towards sustainable e-learning” (p. 819), specifically to surface tensions and contradictions between organizational (management), technological (IT), and pedagogical activity systems within higher education. Like Robertson (2008), our interest is responding to an increase in the diversity of e-learning opportunities and participants. Our focus on MOOCs highlights tensions and contradictions inherent in MOOCs that support both formal and informal learning opportunities.

Activity theory provides a common lexicon to describe formal and informal learning opportunities (Bradshaw et al., 2017) in terms of subjects, tools, objects/outcomes, rules, community, and division of labour. In an informal learning activity system, learners primarily engage in a looselydefined network of learning resources. Learning activities are necessarily learner-directed and loosely structured. Social norms influence interactions among learners and peers, absent formal credentialing through assessment, and a lack of institutional, curricular, and instructional authorities. Success and its measures are broadly conceived. Design patterns emerge from community activities. In a formal learning activity system, learners engage in individual sense-making of a knowledge domain mediated by defined learning resources, such as textbooks. The object, knowledge advancement, gives meaning to the formal learning activities inscribed in a predetermined design. Standardized theories of learning influence design. Institutional policies, directives, and expectations influence interactions. Learning tasks and target outcomes are pre-defined and often highly structured. Assessment criteria are linked to the credential being sought. Learning can be predominantly teacher driven. Figure 3 explores a MOOC as an instance of e-learning conceptualized as potentially contradictory, interactive activity systems.

\section{Figure 3}

Interacting Learning Activity Systems within a MOOC

\begin{tabular}{|c|c|c|}
\hline $\begin{array}{l}\text { ACTIVITY SYSTEM A } \\
\text { Informal Learning }\end{array}$ & $\begin{array}{l}\text { CHAT } \\
\text { ELEMENTS }\end{array}$ & $\begin{array}{l}\text { ACTIVITY SYSTEM B } \\
\text { Formal Learning }\end{array}$ \\
\hline Web 2.0 Applications & $\begin{array}{l}\text { Mediating } \\
\text { Artefacts }\end{array}$ & LMS \\
\hline Learners & Subjects & Learners \\
\hline $\begin{array}{l}\text { 1.Engaging with Web } 2.0 \\
\text { applications primarily for the } \\
\text { purpose of informal sense-making }\end{array}$ & $\begin{array}{l}\text { Goals } \\
\text { (Object } 1 \text { or } 2 \text { ) }\end{array}$ & $\begin{array}{l}\text { 2. Engaging in an LMS class primarily for the purpose } \\
\text { of formal sense-making (and potentially to earn a } \\
\text { credential) }\end{array}$ \\
\hline Online social norms: Netiquette & Rules & $\begin{array}{l}\text { Higher education policies, directive, and expectations, } \\
\text { based on standardized learning theories }\end{array}$ \\
\hline Social media-based e-learning & Community & Traditional higher education, course-based e-learning \\
\hline $\begin{array}{l}\text { Participant-defined roles and } \\
\text { responsibilities }\end{array}$ & $\begin{array}{l}\text { Division of } \\
\text { Labour }\end{array}$ & Teacher-defined roles and responsibilities \\
\hline
\end{tabular}


If tensions within or between CHAT elements within a MOOC design become unmanageable contradictions, then there is a possibility for the emergence of a new activity system: Activity System $\mathrm{C}$ - a MOOC-specific activity system.

\section{Context of the Study}

Our study centered on a MOOC design inspired by The Frankenstein Bicentennial Project (Arizona State University, 2014). The MOOC encouraged thought-provoking investigation, discussion, and ideas around the central concepts of the novel, Frankenstein, and post-humanism. The MOOC design aimed to encourage both formal and informal learning opportunities.

\section{Methodology}

The key research question for the study was "How do instructional designers perceive learners' opportunities for boundary crossing between formal and informal learning within a MOOC design?" Our case study was bound by time and context and included multiple data sources (Merriam, 2009). Eight instructional designers, working in universities in Canada and the United States, participated in the study and were invited to examine a MOOC design (MWS1818 From Frankenstein to Posthumanism) housed in a Blackboard CourseSites LMS for ease of access. Data validation was addressed primarily through triangulation, that is, "a process of using multiple perceptions to clarify meaning, verifying the repeatability of an observation or interpretation" (Stake, 1995, p. 241).

\section{Methods}

Data was collected first through a Likert style questionnaire, followed by two focus group interviews followed by one-on-one interviews. Data were analyzed by identifying corroborations of themes within and across data collection methods. In our report of findings, participants have been identified by markers ID1 through ID8 (Note that one participant self-selected to complete only the survey).

Data analysis of the in situ case study considered the need for a design approach "to teaching and learning" that can "maximize the capabilities of the e-learning medium" (Garrison, 2011, p. 56). Our thematic approach to data analysis focused on "understanding potential synergies between contexts [as] a new area of research that raises questions about how to cross-pollinate learning opportunities across settings" (Bransford et al., 2006, p. 25). Therefore, we focused on identifying participants' perceptions of both tensions that indicated potential contradictions within and across activity systems and the potential for contradictions to identify the emergence of synergies as a potential outcome of boundary crossings. 


\section{Findings and Implications}

Seven of the main fifteen survey questions focused on formal learning activity in the MOOC. Participant responses overall indicated higher levels of agreement, for opportunities for formal learning activities within the MOOC design, than disagreement (see Table 1).

\section{Table 1}

Formal and Informal Learning Survey Results Comparison

\begin{tabular}{lcccccc}
\hline MOOC DESIGN & \multicolumn{2}{l}{ Introduction Units } & \multicolumn{2}{l}{ Core Units } & \multicolumn{2}{l}{ End Units } \\
& SA+A & SD+D & SA+A & SD+D & SA+A & SD+D \\
\hline Formal Learning & 35 & 21 & 30 & 26 & 31 & 25 \\
\hline Informal Learning & 21 & 43 & 24 & 40 & 31 & 33 \\
\hline SUM & 56 & 64 & 54 & 66 & 62 & 58
\end{tabular}

Note. $\mathrm{SA}=$ strongly agree, $\mathrm{A}=$ agree, $\mathrm{SD}=$ strongly disagree, and $\mathrm{D}=$ disagree.

Using CHAT elements to analyze data collected from professional instructional designers' perspectives of one MOOC design identifies potential tensions and contradictions indicated that inclusion of both formal and informal learning activities within a single MOOC design are likely to result in (a) at least, the potential for future learners to cross boundaries between formal and informal activity systems; and, (b) even more likely, result in the emergence of a new, MOOC-specific activity system (Bradshaw et al., 2017). The following findings are discussed: boundary crossing, informal learning language, and MOOC design implications.

\section{Potential for Boundary Crossings}

Participants' responses to focus group and interview questions directly related to boundary crossing indicated perceived possibilities for future learners in the MOOC to mix or crossover between formal and informal learning activities. ID7 stated "the course was open enough to where people could participate in different points, just kind of pick and choose where they wanted to come in and out, and I see some opportunities for that in some of the activities." The crossover or mix was also identified by ID5, who said, "I see it [boundary crossing] is always possible everywhere in the MOOC." ID1 corroborated this claim with "I agree with ID5's basic points that there is crossover everywhere."

Study data revealed themes, which identified boundary objects, and thus potential boundary crossing within and between formal and informal learning activity systems. Boundary crossing was observed within three other themes (directly related to CHAT elements): purpose and potential (objectives); individual in community (community); and direction and self-directed (division of labour). The CHAT element, object(ive), involves "the goal or motive of the activity represented" (YamagataLynch, 2010, p. 22). Our findings surfaced the theme purpose and potential highlighting quaternary tension between participant perceptions of formal learning such as "defined outcomes...goal or end" 
(ID4), and "explicit learning objectives" (ID1) and informal learning where there may not be "an intended learning outcome or product" (ID6). This dichotomy embodies a tension between "specific purpose of transmission" (Scribner \& Cole, 1973, p. 555) in formal learning, and "no pre-defined expectations" suggested by McAuley et al. (2010, p. 4).

In the themes directed and self-direction, contradictions associated with quaternary tensions that can become boundary crossings, arose in relation to the CHAT element division of labour, or who "is responsible for what, when carrying on the activity, and how is the role organized" (Mwanza \& Engeström, 2005, p. 459). Variant participant perceptions identified tasks designed for teacher-guided (or formal) learning activities versus tasks designed to be learner-directed (often identified as informal learning) could be interpreted as expectations, within both formal and informal learning, "the individual's capacity to sift through, filter, find and utilize various networks to retrieve resources and ideas" (Ryberg et al., 2012, p. 43).

During the focus groups, closer investigation of themes offered insights into participant perceptions of tertiary and possibly quaternary contradictions that future learners could encounter in the MOOC design. Such contradictions could cause the emergence of a new activity system that involved learners moving back and forth between designed activities within the LMS and learner-initiated external activities in Web 2.0 applications: "connection through social media" (ID5), through "Google Hangouts" (ID6; ID7), “blog or chat" (ID2), “Twitter feed” (ID7), “Google” (ID6), "website” (ID2), and "YouTube" (ID6).

Boundary crossings "occur because human beings are involved in multiple activities and have to move between them" (Engeström, 2009b, p. 315). Crossing boundaries "between activity systems" and the resultant potential "for forming a new activity system may lead to expansive learning activities, which "produce culturally new patterns of activity" (Engeström, 2001, p. 139). However, culturally new patterns of activity also disrupt established norms and practices. Evidence was identified in the terminology designer-participants used to describe attempts to design for informal learning activities.

\section{Informal Learning Language}

The term "informal" contains the negative prefix "in." Language used by designer-participants in our study to describe and define informal learning opportunities often involved negative wording. Participants, during the focus groups, referred to opportunities for informal learning as opposite to or "not" formal learning. As instructional designers in formal academic institutions, designer-participants appeared to envision informal learning as the absence of a design for formal learning. Across data sets negative descriptors identified informal learning as something with "not an intended learning outcome or product" (ID6), "very unstructured" (ID5), or there "aren't instructions" (ID3) and "not...facilitated" (ID7).

Similar language is echoed in literature that defines informal learning with negative prefixes. For example, "unplanned" (Tusting, 2003, p. 8), "unpremeditated" (Tusting, 2003, p. 5) "incidental" (Wright et al., 2013, p. 54), "non-standardized" (Crowley et al., 2014, p. 466), and "independent” (Schwier \& 
Seaton, 2013, p. 2). Using negative prefixes adds negative connotations to the term, informal learning, setting it in opposition to positive connotations for terms that describe formal learning.

A primary location for instructional design is within formal learning contexts, and all eight research participants worked within such a context. Their focus was to prepare formal learning environments. Their use of negative terms supports Tustings' (2003) claim that informal learning is "often implicitly taken to mean simply the opposite of" (p. 6) formal learning. For example, participant ID1 defined informal learning as "the other types of learning that is not necessarily designed for and is not necessarily assessed." ID5 built on this by adding "similar to ID1, I see it as learning that is occurring by interacting with the materials in a way that wasn't intended." Definitions of informal learning from the literature and the participants' perceptions of informal learning describe what it is not rather than what it is.

In higher education, formal learning "is a term associated with what happens in educational institutions and their programmes and settings. This framing of formal learning suggests a preference for such settings, which tends to shape judgements about learning experiences" (Billet, 2013, p. 131). It is therefore likely that informal learning may not factor as a component in participants' course design work and training as instructional designers. Identifying and analyzing opportunities for informal learning in a MOOC design may exist outside their instructional design experience, lexicon, and practices.

\section{MOOC Design Implications}

At the outset of this study, it was considered that the research might offer insights into formal and informal learning, and boundary crossing to support e-learning instructional designers to proceed from a more informed perspective in terms of design and development of MOOCs.

Extending from the research findings, conclusions, and implications, our case - framed by Engeström's (2009a) third generation CHAT — could be proposed as a model for mapping MOOC design. In our study, CHAT provided an approach for analyzing activity systems, broadly conceived from learning context (formal and informal) types of MOOCs (xMOOCs and cMOOCs) to a specific instance of a MOOC design. It seems possible to extend the approach used in this study to propose a model for mapping activity in a MOOC, given our findings as supported by the literature. Figure 4 envisions a CHAT model for the analysis phase for a MOOC design. 


\section{Figure 4}

CHAT Inspired Model for the Analysis Phase of Designing a MOOC

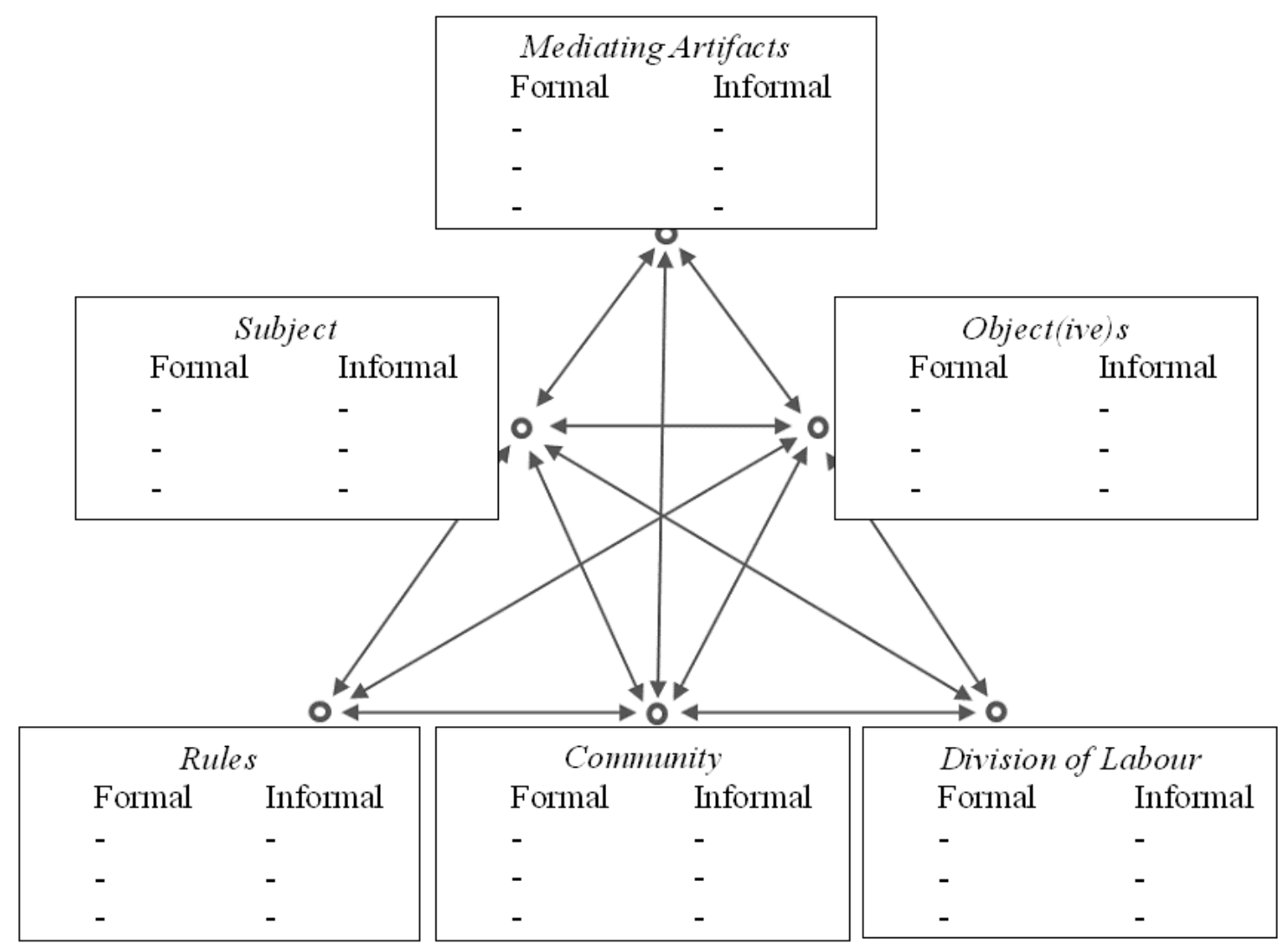

In the model (see Figure 4) CHAT elements are presented with formal and informal subheadings. This model supports the notion of formal and informal learning as a spectrum, and that MOOCs "can fit along any point of this spectrum; i.e. they can be used by individuals to support informal learning...through to receiving full accreditation and being part of an institutional provided formal course" (Conole, 2014, p. 72). This model allows, at the design or any other stage of MOOC creation, mapping formal and informal learning in a MOOC, providing an overall image of the design. An approach to MOOC design mapping such as this allows for the identification of primary (within CHAT elements) and secondary tension (between CHAT elements) tension might arise within a MOOC conceived as an activity system comprising opportunities for both formal and informal learning.

An example of how this model might function can be provided by taking the mapping tool in Figure 5 and filling it in with examples taken from findings from our study. Figure 5 shows the mapping tool with the elements from our study to demonstrate how the tool might be a MOOC mapping tool. 


\section{Figure 5}

MOOC Activity System Mapping Example Using Participant Perceptions of Formal and Informal Learning Activity Systems

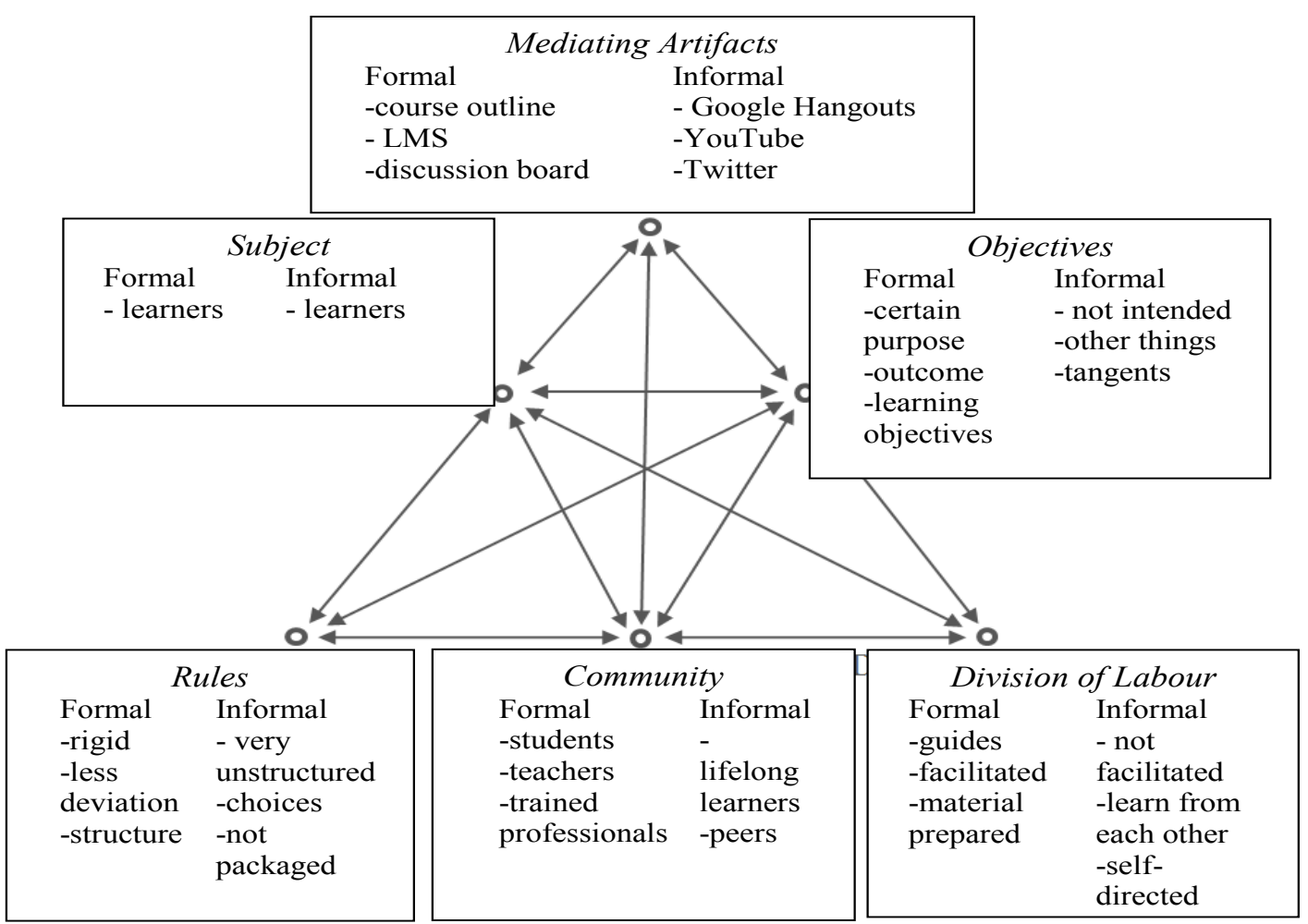

In Figure 5, CHAT offered an example of mapping aspects of both formal and informal learning at the design stage of a MOOC. The approach to mapping in Figure5 might also apply at any stage-from conception to implementation--of formal and informal MOOC instructional design.

\section{Limitations and Directions for Future Research}

The primary limitation of the study was that since it involved studying a MOOC design preimplementation it allowed limited insights into the CHAT subject (future learners). This limitation points to potential directions for future research, including design-based research where iterations of instructional designers' perceptions of opportunities for boundary crossings between formal and informal activities could be compared with those of learners participating in the MOOC. This extension of our research would allow insights into the subjects' (learners') perceptions compared to instructional designers' perceptions. Therefore, it would be interesting to expand the study into the implementation phase to see if the findings would be similar and/or different and why. 


\section{Conclusion}

Activity theory provides the opportunity to make the elements that underpin formal and informal e-learning, such as a MOOC, more explicit. Identification of tensions between activity systems provides opportunities for expansionist learning; potential for a new, hybrid, activity system emerges. This hybrid offers the potential e-learning as a catalyst for developing pedagogical paradigms for sustainability. Instructional design that includes a vision of sustainable e-learning can involve both formal and informal e-learning. A CHAT-based designer/educator-lexicon can re-conceptualize perceptions of and e-learning design practices.

In 1999, Jonassen and Rohrer-Murphy argued that "activity theory provides an appropriate framework for analyzing needs, tasks, and outcomes for designing" constructivist learning environments. Findings and implications from our case study - framed by Engeström's (2009a) third generation CHAT — are posited as a model for mapping the analysis phase creating a MOOC. We found Engeström's CHAT framework provided an effective approach for analyzing a specific instance of a MOOC design to reveal a potential for future learners to encounter contradictions that could lead to the emergence of a new activity system to reconcile formal and informal learning CHAT elements. We suggest that it is possible to extend our model for mapping sustainable e-learning activities in MOOC designs to broader e-learning contexts that can benefit from a blend of formal and informal learning opportunities. 


\section{References}

Anders, A. (2015). Theories and applications of massive open online courses (MOOCs): The case for hybrid design. International Review of Research in Open and Distance Learning, 16(6), 39-61. https://doi.org/10.19173/irrodl.v16i6.2185

Arizona State University (2014). The Frankenstein bicentennial project. Center for Science and the Imagination. http://csi.asu.edu/category/projects/frankenstein-bicentennial/

Billet, S. (2013). Learning through practice: Beyond informal and towards a framework for learning through practice. In Revisiting Global Trends in TVET: Reflections on theory and practice (pp. 123-163). UNESCO.

Bonderup Dohn, N. (2009). Web 2.0: Inherent tensions and evident challenges for education. International Journal of Computer Supported Collaborative Learning, 4(3), 343-363. https://doi.org/10.1007/s11412-009-9066-8

Bradshaw, K., Parchoma, G., \& Lock, J., (2017). Conceptualizing formal and informal learning in MOOCS as activity systems. Quarterly Review of Distance Education, 18(3), 33-50.

Bransford, J. D., Barron, B., Pea, R. D., Meltzoff, A., Kuhl, P., Bell, P., Stevens, R., Schwartz, D. L., Vye, N., Reeves, B., Roschelle, J., \& Sabelli, N. H. (2006). Foundations and opportunities for an interdisciplinary science of learning. In R. K. Sawyer (Ed.), The Cambridge handbook of the learning sciences (pp. 19-34). Cambridge University Press. https://doi.org/10.1017/cbo9780511816833.003

Confrey, J. (2006). The evolution of design studies as methodology. In R. K. Sawyer (Ed.), The Cambridge handbook of the learning sciences (pp. 461-472). Cambridge University Press. https://doi.org/10.1017/cbo9780511816833.010

Conole, G. (2014). A new classification schema for MOOCs. The International Journal for Innovation and Quality in Learning, 2(3), 65-77.

Coursera. (2017). Partnerships. https://www.coursera.org/about/partners

Crowley, K., Pierroux, P., \& Knutson, K. (2014). Informal learning in museums. In R. K. Sawyer (Ed.), The learning sciences, $2^{\text {nd }}$ Ed. (pp. 19-34). Cambridge University Press. https://doi.org/10.1017/cbo9781139519526.028

Downes, S. (2008). Places to go: Connectivism \& connective knowledge. Innovate, 5(1). Retrieved from $\mathrm{http}: / /$ www.innovateonline.info/index.php?view=article \&id $=668$

Downes, S. (2018). Visions and pathways: Online learning and MOOCs. Proceedings Article. May 02, 2018. China International Distance Education Conference, Beijing, China. https://www.downes.ca/files/Visions\%20and\%20Pathways.pdf

Engeström, Y. (2001). Expansive learning at work: Toward an activity theoretical reconceptualization. Journal of Education at Work, 14(1), 133-156. https://doi.org/10.1080/13639080020028747 
Engeström, Y. (2009a). Expansive learning: Towards an activity-theoretical reconceptualization. In K. Illeris (Ed.), Contemporary theories of learning (pp. 53-73). Routledge.

Engeström, Y. (2009b). The Future of Activity Theory: A Rough Draft. In A. Sannino, H. Daniels, \& K. Gutiérrez (Eds.), Learning and Expanding with Activity Theory (pp. 303-328). Cambridge: Cambridge University Press. https://doi.org/10.1017/cbo9780511809989.020

Engeström, Y. (2011). From design experiments to formative interventions. Theory \& Psychology 21(5), 598-628. https://doi.org/10.1177/0959354311419252

Garrison, R. D. (2011). E-learning in the $21^{\text {st }}$ century. Routledge.

Haber, J. (2014). MOOCs. MIT Press.

Hall, R. (2009). Towards a fusion of formal and informal learning environments: The impact of the $\mathrm{read} /$ write web. Electronic Journal of e-Learning, 7(1), 29-40.

Johnson, L., Adams Becker, S., Cummins, M., Estrada, V., Freeman, A., \& Ludgate, H. (2013). NMC Horizon Report: 2013 Higher Education Edition. The New Media Consortium.

Jonassen, D. H., \& Roher-Murphy, L. (1999). Activity theory as framework for designing constructivist learning environments. Education Technology Research \& Development, 47(1), 61-79. https://doi.org/10.1007/bf02299477

Jordan, K. (2014). Initial trends in enrolment and completion of massive open online courses. The International Review of Research in Open and Distance Learning, 15(1), 133-159. https://doi.org/10.19173/irrodl.v15i1.1651

Lewin, T. (2013, July 10). Coursera, an online education company, raises another $\$ 43$ million. The New York Times.

Livingstone, D. W. (2007). Re-exploring the icebergs of adult learning: Comparative findings of the 1998 and 2004 Canadian surveys of formal and informal learning practices. The Canadian Journal for the Study of Adult Education, 1(24).

Malcolm, J., Hodkinson, P., \& Colley, H. (2003). The interrelationships between informal and formal learning. Journal of Workplace Learning, 15(7/8), 313-318. https://doi.org/10.1108/13665620310504783

McAuley, A., Stewart, B., Siemens, G., \& Cormier, D. (2010). The MOOC model for digital practice (Report). University of Prince Edward Island, Social Sciences and Humanities Research. https://oerknowledgecloud.org/sites/oerknowledgecloud.org/files/MOOC Final_0.pdf

Merriam, S. B. (2009). Qualitative research: A guide to design and implementation. John Wiley \& Sons.

Milligan, A., Littlejohn, C., \& Margaryan, A. (2013). Patterns of engagement in connectivist MOOCs. JOLT, 9(24). http://jolt.merlot.org/vo19no2/milligan 0613.htm

Mwanza, D., \& Engeström, Y. (2005). Managing content in e-learning environments. British Journal of Educational Technology, 36(3), 453-463. https://doi.org/10.1111/j.1467-8535.2005.00479.x 
O'Toole, R. (2013) Pedagogical strategies and technologies for peer assessment in Massively Open Online Courses (MOOCs). [Unpublished manuscript]. University of Warwick. http://wrap.warwick.ac.uk/54602/

Robertson, I. (2008). Sustainable e-learning, activity theory and professional development. Ascilite, (pp. 819-826). http://www.ascilite.org.au/conferences/melbourne08/procs/robertson.pdf

Rückriem, G. (2009). Digital technology and mediation: A challenge to activity theory. In A. Sannino, H. Daniels, \& K. D. Gutierrez (Eds.), Learning and expanding with activity theory, (pp. 88-111). Cambridge University Press. https://doi.org/10.1017/cbo9780511809989.007

Ryberg T., Buus L., \& Georgsen M. (2012). Differences in Understandings of Networked Learning Theory: Connectivity or Collaboration? In: Dirckinck-Holmfeld L., Hodgson V., McConnell D. (Eds) Exploring the Theory, Pedagogy and Practice of Networked Learning. Springer, New York, NY. https://doi.org/10.1007/978-1-4614-0496-5 3

Schwier, R. A., \& Seaton, J. X. (2013). A comparison of participation patterns in selected formal, nonformal, and informal learning environments. Canadian Journal of Learning and Technology, 39(1), 1-15. https://doi.org/10.21432/t2g01q

Scribner, S., \& Cole, M. (1973). Cognitive Consequences of Formal and Informal Education: New accommodations are needed between school-based learning and learning experiences of everyday life. Science, 182(4112), 553-559. https://doi.org/10.1126/science.182.4112.553

Schuh, K.L., \& Barab, S. A. (2007). Philosophical perspectives. In J. Spector, M. Merrill, J. van Merrienboer and M. Driscoll (Eds.), Handbook for research in educational technology (pp.6782). Routledge/Taylor and Francis Group.

Selwyn, N., \& Simons, H. (2009). Evolution and concept of case study research. In H. Simons (Ed.), Case study research in practice (pp. 12-28). SAGE Publications.

Siemens, G. (2005, April 5). Connectivism: A learning theory for a digital age [Web log page]. http://www.elearnspace.org/Articles/connectivism.htm

Stake, R. (1995). The art of case study research. SAGE.

Tusting, K. (2003). A review of theories of informal learning (Literacy Research Centre Working Paper No. 2). Lancaster University.

Vernon, J. (2013, April 29). Open online courses - an avalanche that just might get stopped. The Guardian. http://www.theguardian.com/education/2013/apr/29/massive-open-online-courses

Wright, S., Short, B., \& Parchoma, G. (2013). Supporting creativity in craft brewing: A case study in iPhone use in the transition from novice towards mastery. International Journal of Mobile and Blended Learning, 5(3), 52-67. https://doi.org/10.4018/jmbl.2013070104

Yamagata-Lynch L.C. (2010) Understanding Cultural Historical Activity Theory. Activity Systems Analysis Methods, (pp. 13-26). https://doi.org/10.1007/978-1-4419-6321-5 2 


\section{Authors}

Kathlyn Bradshaw, EdD is a Professor in the School of Business, Algonquin College. Her specialization is in professional and workplace communications. Dr. Bradshaw's research interests involved research into open educational resources (OER), specifically cultural historical activity theory and massive open online course (MOOC) design. Email: bradshk@algonquincollege.com

Jennifer Lock, PhD, is a Professor and Vice Dean in the Werklund School of Education, University of Calgary. Her area of specialization is in the Learning Sciences. Dr. Lock's research interests are in elearning, change and innovation in education, scholarship of teaching and learning, and learning in makerspaces. Email: jvlock@ucalgary.ca

Gale Parchoma was an Associate Professor in the Department of Curriculum Studies: Educational Technology and Design in the College of Education at the University of Saskatchewan.

(cc) ()

This work is licensed under a Creative Commons Attribution-NonCommercial CC-BYNC 4.0 International license. 